\title{
The Potential of Laterite Soils Deposit South Sulawesi as a Precursor for Na-Poly (Ferro-Sialate) Geopolymers
}

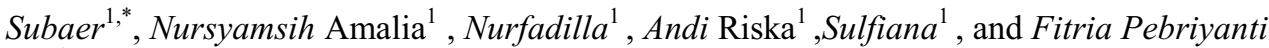 \\ $\mathrm{San}^{1}$ \\ ${ }^{1}$ Material Physics Laboratory, FMIPA, Makassar State University, Makassar 90233, Indonesia
}

\begin{abstract}
The main objectives of this study was to investigate the potential of lateritic soils deposit South Sulawesi, Indonesia as a precursor for Na-poly(ferro-sialate) geopolymers. The samples of laterite soils were taken from three different regions, namely Sidrap, Bone, and Gowa regency. The soil was clean, grounded, sieves 200 mesh, and dehydroxylated at $750^{\circ} \mathrm{C}$ for 2 hours. The $\mathrm{x}$-ray fluorescence (XRF) and energy dispersive spectroscopy (EDS) were used to examine the chemical compositions of the soils. The geopolymers was synthesized through alkali activation method by adjusting the molar oxide ratios of $\mathrm{SiO}_{2} /\left(\mathrm{Al}_{2} \mathrm{O}_{3}+\mathrm{Fe}_{2} \mathrm{O}_{3}\right), \mathrm{Na}_{2} \mathrm{O} / \mathrm{SiO}_{2}$ and $\mathrm{H}_{2} \mathrm{O} / \mathrm{Na}_{2} \mathrm{O}$ in accordance with the chemical compositions of the soils. The functional groups of the resulting geopolymers were examined by using Fourier Transform Infra-Red (FTIR). The structure and phase of the resulting material were studied by using x-ray diffraction (XRD). The surface morphology of geopolymers was studied by using scanning electron microscopy (SEM). The mechanical strength of the materials was examined through compressive strength measurement. The results of this study showed that high strength Na-poly (ferro-sialate) geopolymers were successfully produced and characterized.
\end{abstract}

\section{Introduction}

Laterite is one of a residual soils rich in iron and aluminum formed through weathering processes in tropical areas and subtropical climates [1,2]. Lateritic or laterites soils with a chemical designation of $\mathrm{Fe}_{2} \mathrm{O}_{3}-\mathrm{Al}_{2} \mathrm{O}_{3}-\mathrm{SiO}_{2}-\mathrm{H}_{2} \mathrm{O}$, are derived from kaolinite in which a high proportion of $\mathrm{Al}^{3+}$ is replaced by $\mathrm{Fe}^{2+}$ or $\mathrm{Fe}^{3+}$. Since iron and aluminum oxides are prominent in lateritic soils, and with the seasonal fluctuation of the water table, these oxide result in the reddish to brown in color that is seen in laterite soils [3].

Laterite have been used extensively in construction of dams, embankment as well as buildings, and other environmentally friendly materials $[4,5,6]$. Laterite incorporation in structural concrete elements will likely reduce the cost of construction of buildings significantly. On the other hand, the use of these materials has some tendencies to reduce environmental problems [7].

\footnotetext{
* Corresponding author: jzubayir@yahoo.com
} 
Over the last three decades, geopolymers have been intensively studied as a new form of inorganic polymer material that could substantially substitute for conventional or ordinary Portland cement, plastics, ceramics-composites and many mineral-based products. Geopolymers are a subset of the broader class of alkali-activated binders, and for considerations, it appears to be a potential alternative to the classis hydraulic binders produced at low temperatur $[8,9]$. The defining characteristic of a geopolymer is that the binding phase comprises an alkali aluminosilicate gel, with aluminium and silicon linked in a three-dimensional tetrahedral gel framework that is relatively resistant to dissolution in water $[16,17,8]$. Research has shown that geopolymers may be readily synthesised through alkali-activation of inexpensive and pure starting materials such as kaolinitic clays $[19,20,21]$, as well as waste products such as fly ash and furnace slag [18,22,23,24,25].

The use of laterite soils as a raw material for geopolymers was patented in 2012 by Davidovits, et.al.,[26] and designated as ferro-aluminosilicate type with an empirical formula of $(\mathrm{Ca}, \mathrm{Na}, \mathrm{K}) \cdot(\mathrm{FeO})_{\mathrm{x}} \cdot(\mathrm{SiOAlO})_{1-\mathrm{x}} \cdot(\mathrm{SiO})_{\mathrm{y}}$, where $\mathrm{x}$ is a less than or equal to $0.5, \mathrm{y}$ is a value between 0 and 25 . Several studies followed the utilization of aluminosilicates minerals rich with $\mathrm{Fe}$ in the production of geopolymers [8, 27].

South Sulawesi is one of the provinces in Indonesia where deposit of lateritic soils can be easily found. This research was conducted to investigate the properties of lateritic soils from 3 different sites in South Sulawesi, namely Sidrap, Bone, and Gowa regencies, as potential raw materials for poly-(ferro-sialate) or [Na] [- Fe-0-Si-0-Al-0-] type of geopolymers.

\section{Experimental methods}

This study was conducted to develop South Sulawesi lateritic soils as a raw material for poly-(ferro-sialate) geopolymers. The examples of lateritic soils were taken from three different location; Sidrap, Bone, and Gowa regencies. The examples of soils were clean, immersed in water for 24 hours, dried, grounded and sieved 200 mesh. The soils was dehydroxylated at $750^{\circ} \mathrm{C}$ for 2 hours and subjected to x-ray fluorescence (XRF) or energy dispersive spectroscopy (EDS) examinations to examine its chemical compositions.

Geopolymers were synthesized by varying the molar ratio of $\mathrm{SiO}_{2} /\left(\mathrm{Al}_{2} \mathrm{O}_{3}+\mathrm{Fe}_{2} \mathrm{O}_{3}\right)$, $\mathrm{Na}_{2} \mathrm{O} / \mathrm{SiO}_{2}$, and $\mathrm{H}_{2} \mathrm{O} / \mathrm{Na}_{2} \mathrm{O}$ in accordance with the amount of $\mathrm{SiO}_{2}, \mathrm{Al}_{2} \mathrm{O}_{3}$ and $\mathrm{Fe}_{2} \mathrm{O}_{3}$ available in lateritic soils samples. Sodium silicate solution was used as activator added with $\mathrm{NaOH}$ pellets to increase its $\mathrm{pH}$ up to 13 . The geopolymers gel was molded in accordance with the measurements requirement, cured at $70^{\circ} \mathrm{C}$ for 1 hour. The resulting samples were stored in open air for 28 days.

The functional group of the geopolymers paste was examined by means of Fourier Transform Infra-Red (FTIR). X-ray diffraction (XRD) was used to study the phase and crystallinity of the starting and the resulting materials. Scanning Electron Microscopy-Energy Dispersive Spectroscopy (SEM-EDS) was used to study the surface morphology and chemical compositions of the resulting materials. Compressive strength was measured to examine the mechanical properties of the samples.

\section{Results and discussion}

Figure 1 shows the dehydroxylated laterite soils produced in this research. The soils from Gowa regency contain high amount of $\mathrm{Fe}_{2} \mathrm{O}_{3}$ and appear to be dark brown. 


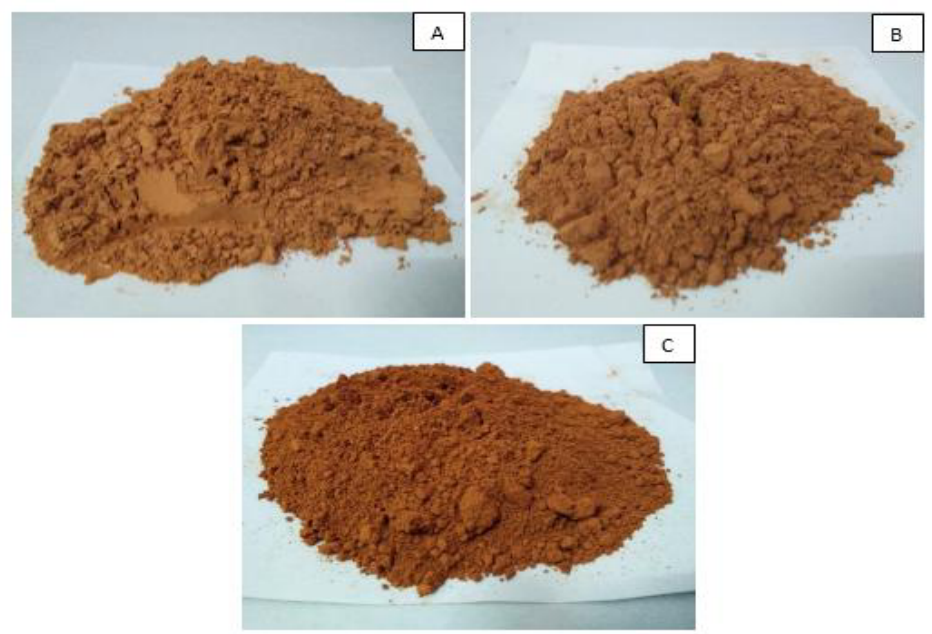

Fig. 1. Dehydroxylated laterite soils from: (a) Sidrap, (b) Bone, and (c) Gowa

Table 1 shows the chemical composition of the soils from three different sites measured by using x-ray fluorescence (XRF). The soils contain $\mathrm{Fe}_{2} \mathrm{O}_{3}$ between $10-30 \mathrm{wt} \%$ indicating the characteristics of lateritic soils. The soils taken from Gowa regency comprise $30.42 \mathrm{wt} \%$ of $\mathrm{Fe}_{2} \mathrm{O}_{3}$ and give dark brown in color.

Table 1. Chemical composition of laterite soils.

\begin{tabular}{|c|c|c|c|}
\hline Compound & Sidrap (wt\%) & Bone (wt\%) & Gowa (wt\%) \\
\hline $\mathrm{SiO}_{2}$ & 47.85 & 50.10 & 30.68 \\
\hline $\mathrm{Fe}_{2} \mathrm{O}_{3}$ & 14.79 & 16.12 & 30.42 \\
\hline $\mathrm{Al}_{2} \mathrm{O}_{3}$ & 32.74 & 22.90 & 30.94 \\
\hline $\mathrm{CaO}$ & 0.240 & 2.41 & - \\
\hline $\mathrm{TiO}_{2}$ & 1.31 & 2.33 & 2.92 \\
\hline $\mathrm{K}_{2} \mathrm{O}$ & 0.864 & 1.09 & - \\
\hline $\mathrm{MnO}$ & 0.151 & 0.366 & 1.21 \\
\hline $\mathrm{SrO}$ & 0.0227 & 0.0732 & - \\
\hline $\mathrm{ZrO}$ & 0.0814 & 0.0679 & 0.0931 \\
\hline $\mathrm{BaO}$ & 0.032 & 0.046 & - \\
\hline $\mathrm{Nb}_{2} \mathrm{O}_{5}$ & 0.0185 & 0.0226 & 0.0265 \\
\hline $\mathrm{MoO}_{3}$ & 0.0122 & 0.0153 & - \\
\hline $\mathrm{ZnO}_{\mathrm{Y} \mathrm{O}_{3}}$ & 0.0110 & 0.0150 & - \\
\hline $\mathrm{In}_{2} \mathrm{O}_{3}$ & 0.0077 & 0.0085 & - \\
\hline & 0.0053 & 0.0077 & 0.0052 \\
\hline
\end{tabular}

Figure 2 shows diffractogram of Dehydroxylated lateritic soils from three different sites. Laterite from Sidrap regency contain high $\mathrm{wt} \%$ of quarzt, while albite mineral was the main species found in laterite Bone regency. Iron oxide in the form of hematite was the main constituent of Gowa lateterite. 


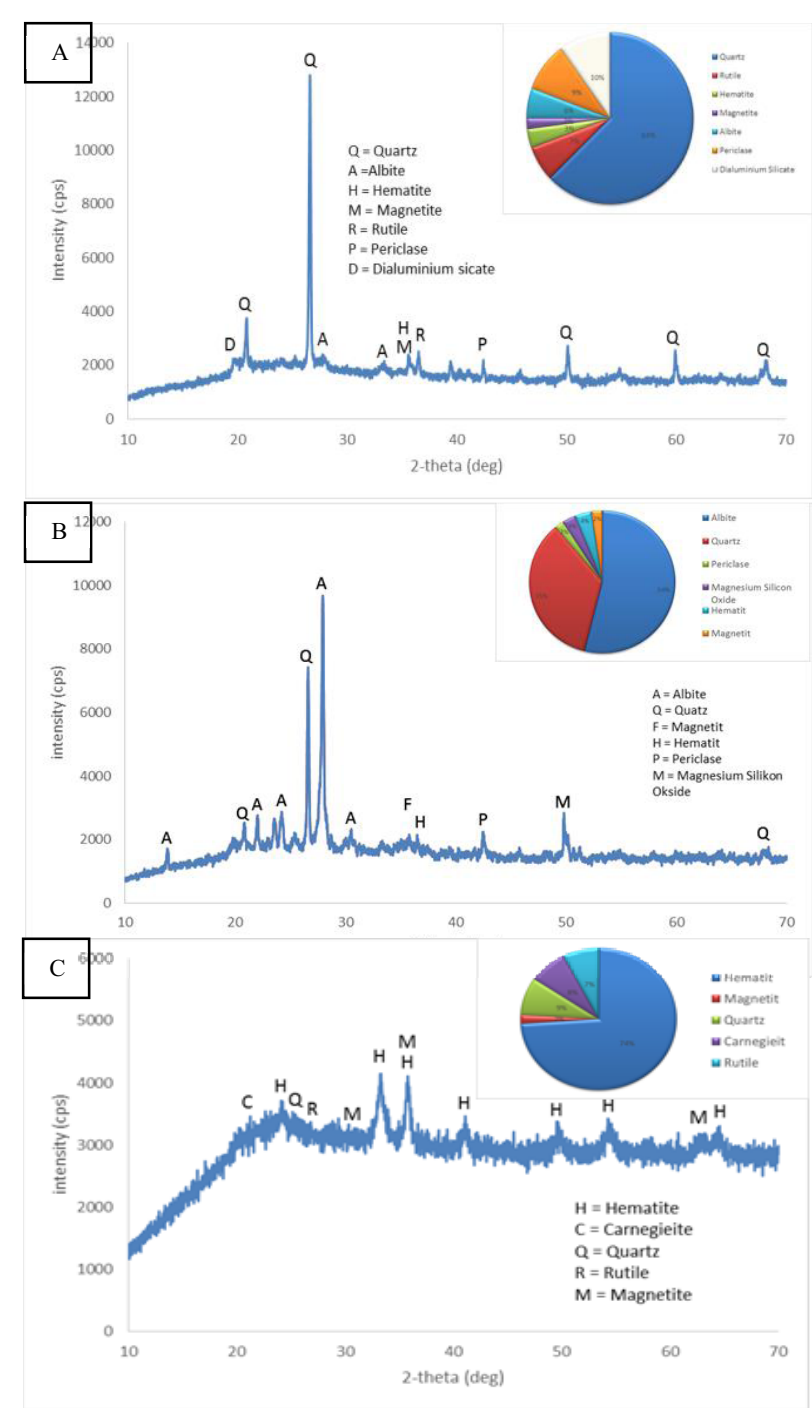

Fig. 2. Diffractogram patterns of laterite soils from (a) Sidrap, (b) Bone, and (c) Gowa.

Figure 3 shows SEM images of dehydroxylated soils from three different sites. The morphology of laterite soils particles from Sidrap shows the shape of kaolinite minerals as this soil contains high percentage of kaolin. Leterite soils from Bone and Gowa contain high percentage of albite and hematite with irregular particles shape. 

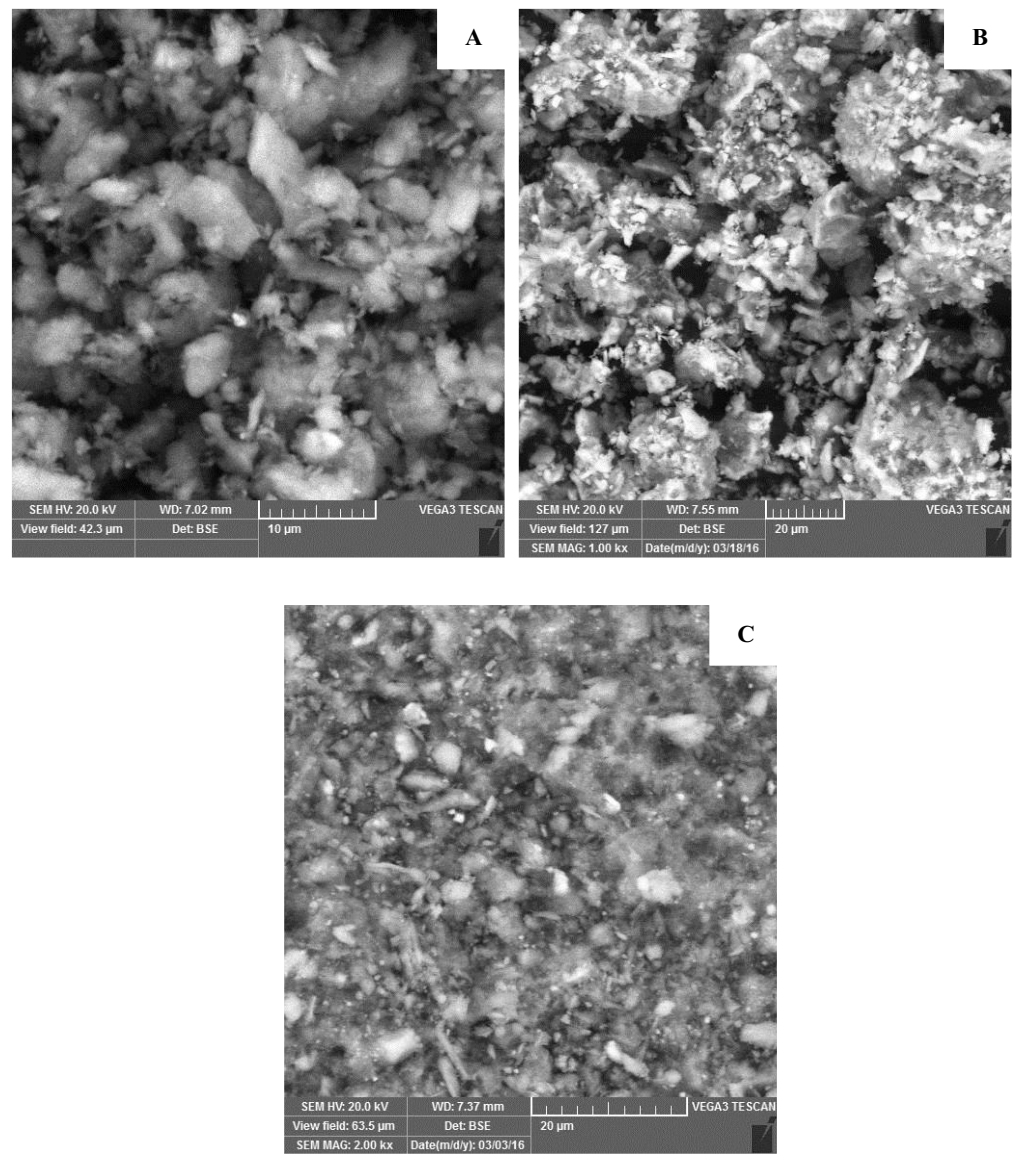

Fig. 3. SEM images of laterite soils from a) Sidrap, b) Bone, and c) Gowa.

Figure 4 displays the IR spectra of product geopolymers made from three different laterite soils. The broad bands appearing at $2316-3351 \mathrm{~cm}^{-1}$ were due to stretching vibrations of $\mathrm{O}-\mathrm{H}$ and $\mathrm{H}-\mathrm{O}-\mathrm{H}$ [11]. The high content of iron oxides of lateritic soil from Gowa (figure 3C) results in slightly different IR bands. The peaks characteristics of water are almost absent indicating that the laterites based inorganic polymers have relatively low water content compared to the standard metakaolin based geopolymers. The band at $1389 \mathrm{~cm}-1$ was attributed as $\mathrm{Al}-\mathrm{OH}$ or $\mathrm{Si}-\mathrm{O}$ vibration. The vibration around $1000 \mathrm{~cm}^{-1}$ was due to a strong band for $\mathrm{Si}-\mathrm{O}-\mathrm{Si}$ stretching vibration and it is the fingerprint of geopolymerisation [12-14]. The $\mathrm{Si}-\mathrm{O}-\mathrm{Al}$ bond was observed between $400 \mathrm{~cm}^{-1}-875 \mathrm{~cm}^{-1}$ indicating the reaction between alkali solution and solid Al-O sheet in the lateritic clays. The bands at $442.35 \mathrm{~cm}^{-1}$ was identified as $\mathrm{Si}-\mathrm{O}-\mathrm{Fe}$ or $\mathrm{Si}-\mathrm{O}$ stretching modes. Vibration band of $\mathrm{Si}-\mathrm{O}-\mathrm{Fe}$ was also found around $468.9 \mathrm{~cm}^{-1}[15]$. The presence of $\mathrm{Si}-\mathrm{O}-\mathrm{Fe}$ vibrations confirmed that the produced geopolymers were categorized as poly(ferro-sialate). 


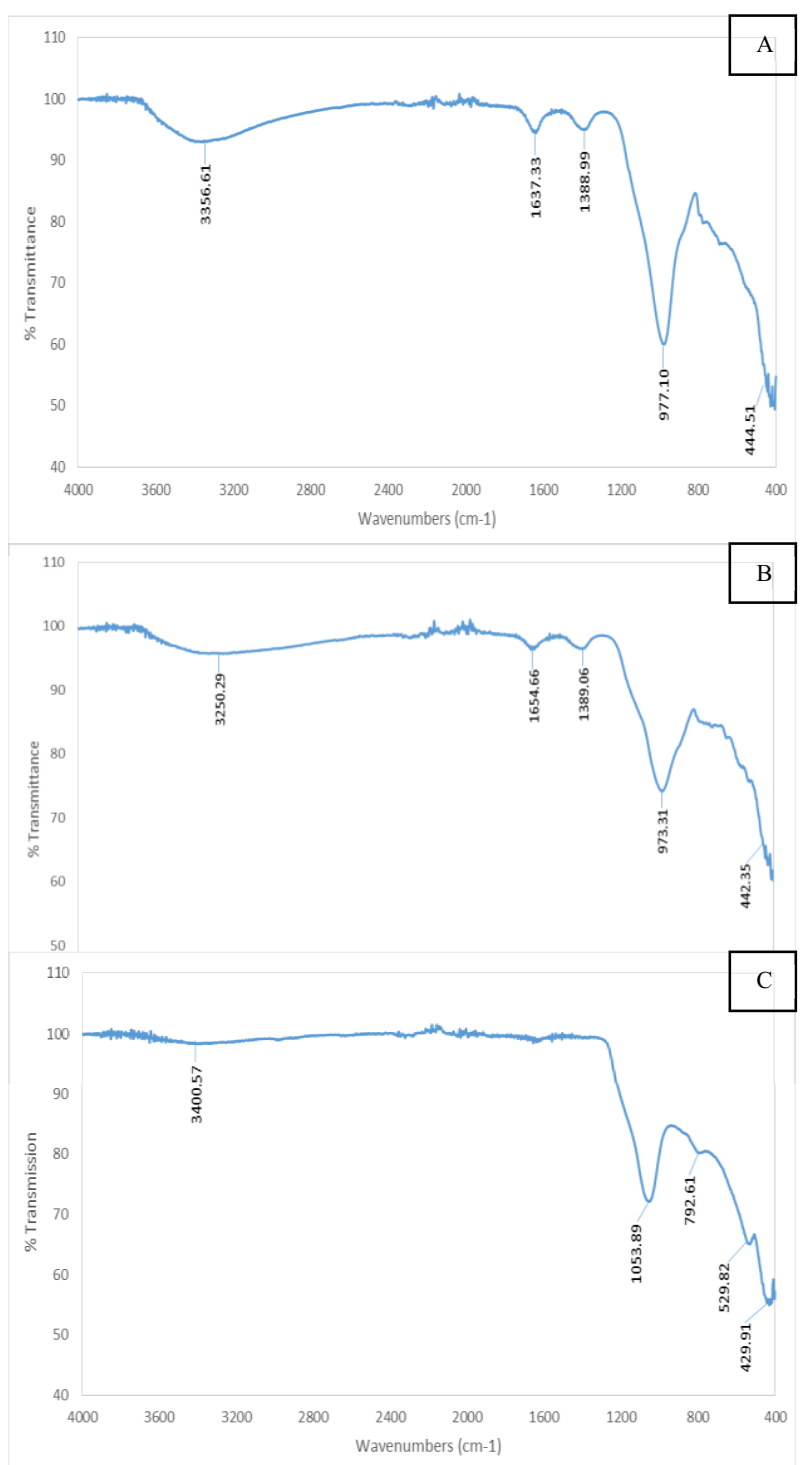

Fig. 4. IR spectra of geopolymer pastes made from laterite soils (a) Sidrap, (b) Bone, and (c) Gowa.

Figure 5 shows $\mathrm{x}$-ray diffractogram of geopolymer pastes produced by using lateritic soils from (a) Sidrap, (b) Bone, and (c) Gowa. Diffaractogram of geopolymer made from Sidrap laterite soils was dominated by almandite and sodium aluminium silicate phases. sampel lanah Sidrap yang menunjukkan fase almandite dan sodium aluminium Silicate yang terbentuk dari reaksi antara aktivator dan bahan dasar. Aegirine phase, (Na)(Fe-Si-Al-O), was observed in geopolymer made from Bone laterite. Sodium iron silicate was observed in geopolymer made from Sidrap and Gowa laterites. The results confirmed that lateritic soils from three different locations produced ferro-sialate type of geopolymers. 


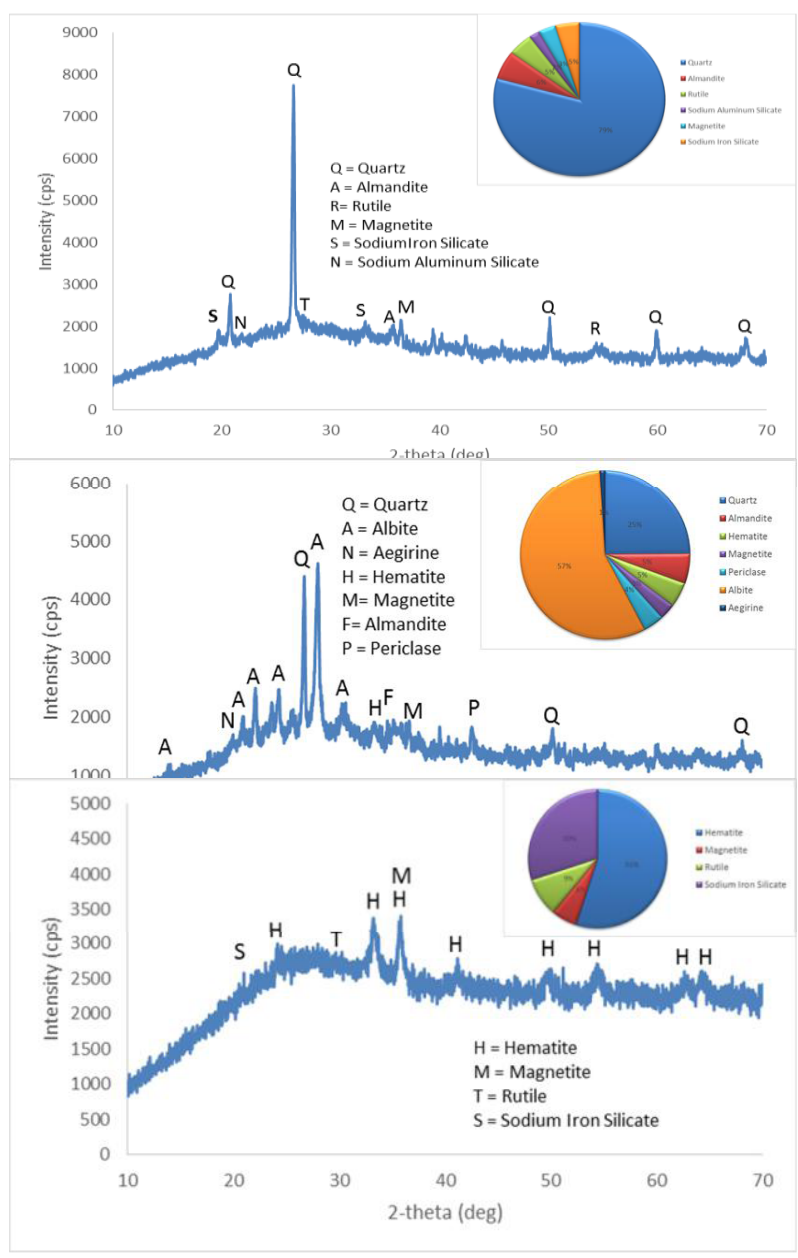

Fig. 5. Diffractogram patterns of geopolymers made from laterite (a) Sidrap, (b) Bone, and (c) Gowa.

SEM examination results of geopoplymer pastes made from lateritic soils is shown in figure 6. The surface of geopolymers made from Sidrap and Gowa laterites suffered from white efflorescence and produced long and sharp crystals of sodium carbonate $\left(\mathrm{Na}_{2} \mathrm{CO}_{3}\left(\mathrm{H}_{2} \mathrm{O}_{7}\right)\right)$ as can be seen in figure 6(a) and (b). SEM image of geopolymer made from Gowa laterite showed the presence of substantial amount of iron oxide particles (bright color). 

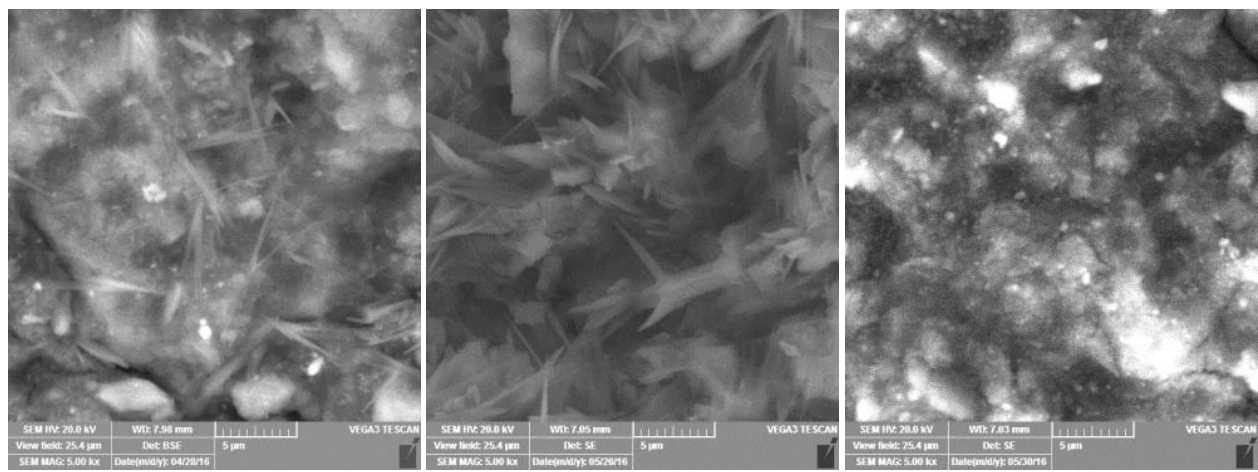

Fig. 6. SEM images of geopolymers paste made from laterites soils (a) Sidrap, (b) Bone, and (c) Gowa

Figure 7 shows the examples of geopolymer pastes made from laterite soils (a) Sidrap, (b) Bone, (c) Gowa for compressive strength measurements. The samples were produced by using acrylic mould and resulting a silinder shape of specimens $4.0 \mathrm{~cm}$ in length and $2.0 \mathrm{~cm}$ in diameter. The compressive strength measurement was conducted after the samples aged 28 days.
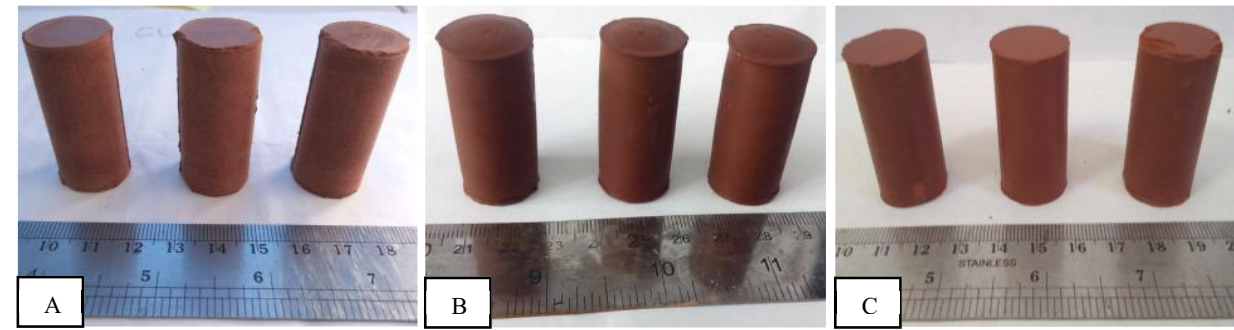

Fig. 7. Examples of geopolymer pastes made from laterite soils (a) Sidrap, (b) Bone, (c) Gowa for compressive strength measurements

Table 2 shows the average magnitude of compressive strength of geopolymer pastes produced from different laterites soils. The value of compressive strength of iron rich-geopolymers produced in this study is similar to those made from metakaolin geopolymer [10]. The compressive strength of Ca-poly(ferro-sialate) type geopolymer is between $60-90 \mathrm{MPa}$ [26]. The difference can be attributed to the type of alkali activator as well as the concentration of iron oxides in lateritic soils used.

Table 2. The average of compressive strength of geopolymers made from laterite soils

\begin{tabular}{|c|c|}
\hline Laterite soils & $\begin{array}{c}\text { Compressive Strength } \\
\text { (MPa) }\end{array}$ \\
\hline Sidrap & 43.24 \\
\hline Bone & 44.88 \\
\hline Gowa & 39.91 \\
\hline
\end{tabular}

\section{Summary}

Iron rich-geopolymers or Na-poly(ferro-sialate) based on three different lateritic soils as raw materials have been successfully produced. The content of iron oxides (hematite and magnetite) of the lateritic soils range from $10-30 \mathrm{wt} \%$. The presence of functional groups of $\mathrm{Si}-\mathrm{O}$ bands and $\mathrm{Si}-\mathrm{O}-\mathrm{Al}$ bands as well as the presence of $(\mathrm{Na})(\mathrm{Fe}-\mathrm{Si}-\mathrm{Al}-\mathrm{O})$ phase confirmed the geopolymerisation of lateritic soils used in this study. The compressive strength of the produced was comparable to those made from metakaolin. 


\section{References}

1. I.E. Kalu, E.E. Jossou, F. Jacob, A.I. Ilboudo, A.F. Adedeji, W.O. Soboyejo, Inter. J. Eng. Technol., 5, 87 (2015)

2. T.H. Ko, ScientificWorldJournal, 1 (2014)

3. P.N. Lemougna, U.F.C. Melo, E. Kamseu, A.B. Tchamba, Sustainability, 3, 293 (2011)

4. I.A. Oyediran, J. Okosun, Provessional Paper, 60, 287 (2012)

5. J.O. Ukpata, M.E. Ephraim, G. A. Akeke, J. Eng. Appl. Sci., 7, 81 (2012)

6. E.A. Adam, Compressed Stabilized Earth Block Manufacture in Sudan ( UNESCO, Paris, 2001)

7. J.O. Ukpata, M.E. Ephraim, J. Eng. Appl. Sci., 7, 324 (2012)

8. W. Hajjaji, S. Andrejkovicova, C. Zanelli, M. Alshaaer, M. Dondi, J.A. Labrincha, F. Rocha, Mater. Des., 52, 648 (2013)

9. F. Skvara, L. Kopecky, J. Nemecek, Z. Bittnar, Ceramics, 50, 208 (2006)

10. Subaer, Pengantar Fisika Geopolimer (Direktorat Jendral Pendidikan Tinggi, Jakarta, 2015)

11. Z. Yahya, M.M. Abdullah, K. Hussin, K.N. Ismail, R.A. Razak, A.V. Sandu, Materials, 8, $2227(2015)$

12. A. Allahverdi, E.N. Kani, Int. J. Civ. Eng., 7, 154 (2009)

13. A.M.M. Bakri, H. Kamarudin, M.B. Hussain, I.K. Nizar, A.R. Rafiza, Y. Zarina, Adv. Meter. Sci., 30, 90 (2012)

14. E. Arioz, O. Arioz, O. M. Kockar, Inter. J. Chem. Eng. Appl., 4, 423 (2013)

15. P.S. Nayak, B. K. Singh, Bull. Mater. Sci., 30, 235 (2007)

16. K.J.D. Mackenzie, What are these things called geopolymers? A physico-chemical perspective, (2003)

17. C.A. Rees, J.L. Provis, G.C. Lukey, J.S.J.V. Deventer, Langmuir, 23, 8170 (2007)

18. C. Shi, P.V. Krivenko, D. Roy, Alkali-activated Cements and Concretes (Taylor \&Francis, London, 2006)

19. J. Davidovits, U.S Patent No.4,349,386 (1982)

20. H. Rahier, B.V. Melle, M. Bieseman, J. Wastiels, X. Wu, J. Mater. Sci., 31, 71(1996)

21. H. Rahier,W. Simons, B.V. Melle, M. Biesemans, J. Mater. Sci., 32, 2237(1997)

22. A. Palomo, M.W. Grutzeck, M.T. Blanco, Cem. Concr. Res., 29, 1323 (1999)

23. J.G.S.V. Jaarsveld, J.S.J.V. Deventer, L. Lorenzen (1997), Miner. Eng., 10, 659 (1997)

24. J.G.S.V. Jaarsveld, J.S.J.V. Deventer, (1999), Cem.Concr. Res., 29, 1189 (1999)

25. A.R. Brough, A. Atkinson, Cem.Concr. Res., 32, 1 (2002)

26. J. Davidovits, F. Davidovits, R. Davidovits, Patent No. WO/2012/056125/2012 (2002)

27. E.A. Obonyo, E. Kamasue, P.N. Lemougna, A.B. Tchamba, U.C. Melo, C. Leonelli, Sustainability, 6, 5535 (2014) 